\title{
Penguatan Kedudukan Peraturan Desa Dalam Sistem Perundang-Undangan Indonesia
}

\author{
Dodi Jaya Wardana, S.H., M.H. ${ }^{1}$ Fakultas Hukum Universitas Muhammadiyah Gresik \\ dodijayawardana@umg.ac.id
}

\begin{abstract}
Abstarct
In Law Number 10 of 2004, Village Regulations are placed as one of the types of Legislation in Indonesia. However, with the birth of Law Number 12 of 2011 concerning the Establishment of Legislation as a substitute for Law Number 10 of 2004 the position of Village Regulations became unclear, even unregulated and not included in the hierarchical system of Legislation in Indonesian. Village Head Regulations, which are the implementing rules of Village Regulations, and are positioned under Village Regulations, are more regulated and incorporated into the Indonesian Legislation System. Furthermore, in Law Number 12 of 2011, regulations regarding hierarchy or position / position of Village Regulations are not regulated. If carefully explored in Law Number 12 of 2011, there is no position in the Village Regulations as a type and explicitly in the hierarchy of Legislation. Therefore, this research is expected to clarify and reinforce the position or position of village regulations in Indonesian legislation. So that Village Regulations can be one of the rules of the Indonesian legislation.
\end{abstract}

\section{Keywords: Strengthening, Position Village Regulations and Indonesia's Invitation System.}

\section{Latar Belakang Masalah}

Peraturan desa ditunjukan sebagai suatu perangkat dasar legitimasi penyelenggara pemerintah desa dalam menjalankan roda pemerintahan desa, dengan kata lain peraturan desa disusun sebagai acuan dalam melaksanakan pemerintahan dan pembangunan di desa. Dalam Pasal 104 UU Nomor 22 Tahun 1999, dinyatakan bahwa Badan Perwakilan Desa atau yang disebut dengan nama lain berfungsi mengayomi adat istiadat, membuat peraturan desa, menampung dan menyalurkan aspirasi masyarakat, serta melakukan pengawasan terhadap penyelenggaraan pemerintahan desa. ${ }^{2}$

Undang-Undang Nomor 22 Tahun 1999 diganti dengan Undang-Undang Nomor 32 Tahun 2004 Tentang Pemerintahan Daerah. Desa menurut UU Nomor 32 tahun 2004 kesatuan

\footnotetext{
${ }^{1}$ Dosen pada Fakultas Hukum Universitas Muhammadiyah Gresik

2 Ni'matul Huda, Perkembangan Hukum Tata Negara Perdebatan Dan Gagasan Penyempurnaan, Cetakan Pertama, Yogyakarta:FH UII Press, h. 361
} 
masyarakat hukum yang memiliki batas-batas wilayah yurisdiksi, wewenang untuk mengatur dan mengurus kepentingan masyarakat setempat berdasarkan asal-usul dan adat istiadat setempat yang diakui dan/atau dibentuk dalam sistem pemerintahan nasional dan berada di kabupaten/kota.

Penyusunan peraturan desa merupakan penjabaran atas berbagai kewenangan yang dimiliki desa, seperti kewenangan yang sudah ada berdasarkan hak asal usul desa, kewenangan yang diproleh melalui peraturan perundang-undangan di atasnya sebagai urusan desa, penjabaran lebih lanjut dari peraturan perundang-undangan dan urusan pemerintahan lainnya yang oleh peraturan perundang-undangan diserahkan kepada desa, yang tentu saja dalam penyusunannya tidak boleh bertentangan dengan kepentingan umum dan peraturan perundang-undangan yang lebih tinggi.

Selanjutnya Undang-Undang Nomor 6 Tahun 2014 tentang Desa, Peraturan Desa ditetapkan oleh Kepala Desa setelah dibahas dan disepakati bersama Badan Permusyawaratan Desa merupakan kerangka hukum dan kebijakan dalam penyelenggaraan Pemerintahan Desa dan Pembangunan Desa. Penetapan Peraturan Desa merupakan penjabaran atas berbagai kewenangan yang dimiliki Desa mengacu pada ketentuan peraturan perundang-undangan yang lebih tinggi. Sebagai sebuah produk hukum, Peraturan Desa tidak boleh bertentangan dengan peraturan yang lebih tinggi dan tidak boleh merugikan kepentingan umum.

Dalam perjalanannya, pengaturan mengenai eksistensi peraturan desa telah mengalami perubahan. Awalnya peraturan desa diakomodir secara eksplisit dalam hierarki perturan perundang-undangan, yakni dalam Pasal 1 angka 8 Undang-Undang Nomor 10 tahun 2004 tentang pembentukan peraturan perundang-undangan disebutkan bahwa: "perauran desa/peraturan yang setingkat adalah peraturan perundang-undangan yang dibuat oleh Badan Perwakilan Desa atau nama lainnya bersama dengan Kepala Desa atau nama lainnya. Dan Pasal 7 ayat (1) jenis dan hierarki peraturan peraturan perundang-undangan adalah sebagai berikut:

a. Undang-Undang Dasar Negaa Republik Indonesia Tahun 1945; b. UndangUndang/Peraturan Pemerintah Pengganti Undang-Undang; c. Peraturan Pemerintah; d. Peraturan Presiden; e. Peraturan Daerah.

Di dalam ayat (2) ditegaskan, Peraturan Daerah sebagaimana dimaksud pada ayat (1) huruf e meliputi: a. Peraturan Daerah Provinsi dibuat oleh Dewan Perwakilan Rakyat Daerah Provinsi bersama dengan Gubernur; b. Peraturan Daerah Kabupaten/Kota dibuat oleh Dewan Perwakilan Rakyat Daerah Kabupaten/Kota bersama dengan Bupati/Walikota; c. Peraturan Desa/peraturan yang setingkat, dibuat oleh Badan Perwakilan Desa atau nama lainnya bersama dengan Kepala Desa atau nama lainnya. Dan ayat (3) menyatakan, ketentuan lebih lanjut 
mengenai tata cara perbuatan peraturan desa/peraturan yang setingkat diatur dengan peraturan daerah kabupaten/kota yang bersangkutan.

Bertolak dari uraian di atas maka dapat dikatakan bahwa dalam Undang-Undang Nomor 10 Tahun 2004, Peraturan Desa di dudukkan menjadi salah satu jenis Peraturan Perundangundangan di Indonesia. Akan tetapi, dengan lahirnya UU No. 12 Tahun 2011 tentang Pembentukan Peraturan Perundang-undangan sebagai pengganti dari UU No. 10 Tahun 2004 kedudukan Peraturan Desa menjadi tidak jelas, bahkan tidak diatur dan tidak di masukkan ke dalam sistem hierarkhi Peraturan Perundang-undangan di Indonesia. Peraturan Kepala Desa yang merupakan aturan pelaksana dari Peraturan Desa, dan berposisi dibawah Peraturan Desa lebih diatur dan dimasukkan ke dalam sistem Peraturan Perundang-undangan di Indonesia.

Selanjutnya di dalam UU No. 12 Tahun 2011, pengaturan mengenai hierarkhi atau posisi/kedudukan Peraturan Desa tidak diatur. Apabila ditelusuri secara seksama UU Nomor 12 Tahun 2011, tidak ditemukan kedudukan Peraturan Desa sebagai jenis dan berposisi dalam hierarkhi Peraturan Perundang-undangan secara eksplisit.

Secara eksplisitas dapat tertelusuri dalam Pasal 7 ayat (1) UU No. 12 Tahun 2011, dalam pasal tersebut diuraikan jenis dan hierarki Peraturan Perundang-undangan sebagai berikut: Undang-Undang Dasar Negara Republik Indonesia Tahun 1945, Ketetapan Majelis Permusyawaratan Rakyat, Undang-Undang/Peraturan Pemerintah Pengganti Undang-Undang, Peraturan Pemerintah, Peraturan Presiden, Peraturan Daerah Provinsi, dan Peraturan Daerah Kabupaten/Kota. Meskipun dalam Pasal 7 ayat (1) UU Nomor 12 Tahun 2011 telah dengan tegas menyebutkan jenis dan hierarki peraturan perundang-undangan, dalam Pasal 8 ayat (1)

UU Nomor 12 Tahun 2011 masih memperluas cakupan peraturan perundang-undangan.

Cakupan jenis Perundang-undangan yang diperluas dalam pasal ini disebutkan secara rinci, sebagai berikut: Jenis Peraturan Perundang-undangan selain sebagaimana dimaksud dalam Pasal 7 ayat (1) mencakup peraturan yang ditetapkan oleh Majelis Permusyawaratan Rakyat, Dewan Perwakilan Rakyat, Dewan Perwakilan Daerah, Mahkamah Agung, Mahkamah Konstitusi, Badan Pemeriksa Keuangan, Komisi Yudisial, Bank Indonesia, Menteri, Badan, Lembaga, atau Komisi yang setingkat yang dibentuk dengan Undang-Undang atau Pemerintah atas perintah Undang-Undang, Dewan Perwakilan Rakyat Daerah Provinsi, Gubernur, Dewan Perwakilan Rakyat Daerah Kabupaten/Kota, Bupati/Walikota, Kepala Desa atau yang setingkat. Dari ketentuan tersebut, persoalan yang muncul adalah dimanakah letak kedudukan (levelitas) Peraturan Desa sebagai jenis dan hierarkinya dalam peraturan Perundang-undangan di Indonesia dengan berlakunya Undang-Undang Nomor 12 Tahun 2011 tentang Pembentukan Peraturan Perundang-Undagan tersebut. Untuk itulah topik mengenai 
penguatan kedudukan peraturan desa dalam sistemperundang-undangan Indonesia layak untuk dikaji dan diteliti.

\section{Rumusan Masalah}

Adapun rumusan masalah dalam jurnal ini adalah dimanakah posisi dan kedudukan peraturan desa dalam sistem perundang-undangan Indonesia setelah mengalami perubahan Undang-Undang.?

\section{Analisa dan Pembahasan}

Peraturan desa ditunjukan sebagai suatu perangkat dasar legitimasi penyelenggara pemerintah desa dalam menjalankan roda pemerintahan desa, dengan kata lain peraturan desa disusun sebagai acuan dalam melaksanakan pemerintahan dan pembangunan di desa. Dalam Pasal 104 UU Nomor 22 Tahun 1999, dinyatakan bahwa Badan Perwakilan Desa atau yang disebut dengan nama lain berfungsi mengayomi adat istiadat, membuat peraturan desa, menampung dan menyalurkan aspirasi masyarakat, serta melakukan pengawasan terhadap penyelenggaraan pemerintahan desa.

Dalam perjalanan selanjutnya UU Nomor 22 Tahun 1999 diganti dengan UndangUndang Nomor 32 Tahun 2004 Tentang Pemerintahan Daerah. Desa menurut UU Nomor 32 tahun 2004 kesatuan masyarakat hukum yang memiliki batas-batas wilayah yurisdiksi, wewenang untuk mengatur dan mengurus kepentingan masyarakat setempat berdasarkan asal-usul dan adat istiadat setempat yang diakui dan/atau dibentuk dalam sistem pemerintahan nasional dan berada di kabupaten/kota. Adapun landasan pemikiran dalam pengaturan mengenai desa adalah keanekaragaman, partisiasi, otonomi asli, demokrasi dan pemberdayaan masyarakat.

Otonomi yang dimiliki oleh desa ataupun sebutan lainnya dan kepada desa melalui pemerintahan desa dapat diberikan penugasan ataupun pendelegasian dari pemerintah ataupun pemerintah daerah untuk melaksanakan urusan pemerintahan tertentu. Sebagai perwujudan demokrasi, dalam penyelenggaraan pemerintahan desa dibentuk Badan Permusyawaratan Desa atau sebutan lain yang sesuai dengan budaya yang berkembang di desa bersangkutan, yang berfungsi sebagai lembaga pengaturan dalam peyelenggaraan pemerintahan desa, seperti dalam pembuatan dan pelaksanaan peraturan desa, anggaran pendapatan dan belanja desa, dan keputusan kepala desa.

Di dalam Pasal 209 UU Nomor 32 Tahun 2004 dijelaskan, bahwa Badan Permusyawaratan Desa berfungsi menetapkan Peraturan Desa bersama Kepala Desa, 
menampung dan menyalurkan aspirasi masyarakat. Kemudian dalam Pasal 212 ayat (5) dinyatakan bahwa pengelolaan keuangan desa sebagaimana dimaksud pada ayat (2) dilakukan oleh kepala desa yang dituangkan dalam peraturan desa tentang anggaran pendapatan dan belanja desa. Adanya pengaturan terkait peraturan desa di atas menunjukkan bahwa desa merupakan suatu pemerintahan atau daerah yang otonom yang dapat menjalankan pemerintahannya sendiri.

Penyusunan peraturan desa merupakan penjabaran atas berbagai kewenangan yang dimiliki desa, seperti kewenangan yang sudah ada berdasarkan hak asal usul desa, kewenangan yang diproleh melalui peraturan perundang-undangan di atasnya sebagai urusan desa, penjabaran lebih lanjut dari peraturan perundang-undangan dan urusan pemerintahan lainnya yang oleh peraturan perundang-undangan diserahkan kepada desa, yang tentu saja dalam penyusunannya tidak boleh bertentangan dengan kepentingan umum dan peraturan perundang-undangan yang lebih tinggi.

Selanjutnya dalam ketentuan Undang-Undang Nomor 6 Tahun 2014 tentang Desa Peraturan Desa ditetapkan oleh Kepala Desa setelah dibahas dan disepakati bersama Badan Permusyawaratan Desa merupakan kerangka hukum dan kebijakan dalam penyelenggaraan Pemerintahan Desa dan Pembangunan Desa. Penetapan Peraturan Desa merupakan penjabaran atas berbagai kewenangan yang dimiliki Desa mengacu pada ketentuan peraturan perundangundangan yang lebih tinggi. Sebagai sebuah produk hukum, Peraturan Desa tidak boleh bertentangan dengan peraturan yang lebih tinggi dan tidak boleh merugikan kepentingan umum

Dalam perjalanannya, pengaturan mengenai eksistensi peraturan desa telah mengalami perubahan. Awalnya peraturan desa diakomodir secara eksplisit dalam hierarki perturan perundang-undangan, yakni dalam Pasal 1 angka 8 UU Nomor 10 tahun 2004 tentang pembentukan peraturan perundang-undangan disebutkan bahwa: "perauran desa/peraturan yang setingkat adalah peraturan perundang-undangan yang dubuat oleh Badan Perwakilan Desa atau nama lainnya bersama dengan Kepala Desa atau nama lainnya. Dan Pasal 7 ayat (1) jenis dan hierarki peraturan peraturan perundang-undangan adalah sebagai berikut: a. Undang-Undang Dasar Negaa Republik Indonesia Tahun 1945; b. Undang-Undang/Peraturan Pemerintah Pengganti Undang-Undang; c. Peraturan Pemerintah; d. Peraturan Presiden; e. Peraturan Daerah. Di dalam ayat (2) ditegaskan, Peraturan Daerah sebagaimana dimaksud pada ayat (1) huruf e meliputi: a. Peraturan Daerah Provinsi dibuat oleh Dewan Perwakilan Rakyat Daerah Provinsi bersama dengan Gubernur; b. Peraturan Daerah Kabupaten/Kota dibuat oleh Dewan Perwakilan Rakyat Daerah Kabupaten/Kota bersama dengan Bupati/Walikota; c. Peraturan Desa/peraturan yang setingkat, dibuat oleh Badan Perwakilan Desa atau nama 
lainnya bersama dengan Kepala Desa atau nama lainnya. Dan ayat (3) menyatakan, ketentuan lebih lanjut mengenai tata cara perbuatan peraturan desa/peraturan yang setingkat diatur dengan peraturan daerah kabupaten/kota yang bersangkutan.

Bertolak dari uraian di atas maka dapat dikatakan bahwa dalam Undang-Undang Nomor 10 Tahun 2004, Peraturan Desa di dudukkan menjadi salah satu jenis Peraturan Perundangundangan di Indonesia. Akan tetapi, dengan lahirnya UU No. 12 Tahun 2011 tentang Pembentukan Peraturan Perundang-undangan sebagai pengganti dari UU No. 10 Tahun 2004 kedudukan Peraturan Desa menjadi tidak jelas, bahkan tidak diatur dan tidak di masukkan ke dalam sistem hierarkhi Peraturan Perundang-undangan di Indonesia. Peraturan Kepala Desa yang merupakan aturan pelaksana dari Peraturan Desa, dan berposisi dibawah Peraturan Desa lebih diatur dan dimasukkan ke dalam sistem Peraturan Perundang-undangan di Indonesia.

Selanjutnya di dalam UU No. 12 Tahun 2011, pengaturan mengenai hierarkhi atau posisi/kedudukan Peraturan Desa tidak diatur. Apabila ditelusuri secara seksama UU Nomor 12 Tahun 2011, tidak ditemukan kedudukan Peraturan Desa sebagai jenis dan berposisi dalam hierarkhi Peraturan Perundang-undangan secara eksplisit.

Secara eksplisitas dapat tertelusuri dalam Pasal 7 ayat (1) UU No. 12 Tahun 2011, dalam pasal tersebut diuraikan jenis dan hierarki Peraturan Perundang-undangan sebagai berikut: Undang-Undang Dasar Negara Republik Indonesia Tahun 1945, Ketetapan Majelis Permusyawaratan Rakyat, Undang-Undang/Peraturan Pemerintah Pengganti Undang-Undang, Peraturan Pemerintah, Peraturan Presiden, Peraturan Daerah Provinsi, dan Peraturan Daerah Kabupaten/Kota. Meskipun dalam Pasal 7 ayat (1) UU Nomor 12 Tahun 2011 telah dengan tegas menyebutkan jenis dan hierarki peraturan perundang-undangan, dalam Pasal 8 ayat (1) UU Nomor 12 Tahun 2011 masih memperluas cakupan peraturan perundang-undangan.

Cakupan jenis Perundang-undangan yang diperluas dalam pasal ini disebutkan secara rinci, sebagai berikut: Jenis Peraturan Perundang-undangan selain sebagaimana dimaksud dalam Pasal 7 ayat (1) mencakup peraturan yang ditetapkan oleh Majelis Permusyawaratan Rakyat, Dewan Perwakilan Rakyat, Dewan Perwakilan Daerah, Mahkamah Agung, Mahkamah Konstitusi, Badan Pemeriksa Keuangan, Komisi Yudisial, Bank Indonesia, Menteri, Badan, Lembaga, atau Komisi yang setingkat yang dibentuk dengan UndangUndang atau Pemerintah atas perintah Undang-Undang, Dewan Perwakilan Rakyat Daerah Provinsi, Gubernur, Dewan Perwakilan Rakyat Daerah Kabupaten/Kota, Bupati/Walikota, Kepala Desa atau yang setingkat.

Dari ketentuan tersebut, persoalan yang muncul adalah dimanakah letak kedudukan (levelitas) Peraturan Desa sebagai jenis dan hierarkinya dalam peraturan Perundang-undangan 
di Indonesia dengan berlakunya Undang-Undang Nomor 12 Tahun 2011 tentang Pembentukan Peraturan Perundang-Undagan dan Undang-Undang Nomor 6 tahun 2014 Tentang Desa.??? Hal inilah yang menjadi fokus dalam penelitian ini.

Dalam sejarah pengaturan Desa, telah ditetapkan beberapa pengaturan tentang Desa, yaitu Undang-Undang Nomor 22 tahun 1948 Tentang Pokok Pemerintahan Daerah, Undang-Undang Nomor 1 tahun 1957 Tentang Pokok-Pokok Pemerintahan Daerah, Undang-Undang Nomor 18 Tahun 1965 Tentang Pokok-Pokok Pemerintahan Daerah, Undang-Undang Nomor 19 Tahun 1965 Tentang Desa Praja Sebagai Bentuk Peralihan Untuk Mempercepat Terwujudnya Daerah Tingkat III Di Seluruh Wilayah Republik Indonesia, Undang-Undang Nomor 5 Tahun 1974 Tentang Pokok-Pokok Pemerintahan di Daerah, Undang-Undang Nomor 5 Tahun 1979 Tentang Pemerintahan Desa, Undang-Undang Nomor 22 Tahun 1999 Tentang Pemerintahan Daerah, Undang-Undang Nomor 32 Tahun 1965 Tentang Pemerintahan Daerah, dan yang terbaru Undang-Undang Nomor 23 Tahun 2014 Tentang Pemerintahan Daerah.

Dalam pelaksanaannya, pengaturan mengenai Desa tersebut belum dapat mewadahi segala kepentingan dan kebutuhan masyarakat Desa yang hingga saat ini sudah berjumlah sekitar 73.000 (Tujuh Puluh Tiga Ribu) Desa dan sekitar 8.000 (Delapan Ribu) kelurahan. ${ }^{3}$ Selain itu, pelaksanaan pengaturan Desa yang selama ini berlaku sudah tidak sesuai lagi dengan perkembangan zaman, terutama antara lain menyangkut kedudukan masyarakat, demokratisasi, keberagaman, partisipasi masyarakat, serta kemajuan dan pemerataan pembangunan sehingga menimbulkan kesenjangan antarwilayah, kemiskinan, dan masalah social budaya yang dapat mengganggu keutuhan Negara Kesatuan Republik Indonesia.

Berkaitan dengan status hukum atau keberadaan Peraturan Desa dalam Undang-Undang Nomor 6 tahun 2014 teng Desa yang menjadi focus kajian dalam penulisan Penelitian ini, di dalam Pasal 69 di tentukan Jenis Peraturan di Desa terdiri atas Peraturan Desa, Peraturan bersama Kepala Desa, dan Peraturan Kepala Desa. Peraturan di Desa dilarang bertentangan dengan kepentingan umum dan/atau ketentuan Peraturan perundang-undangan yang lebih tinggi. Peraturan Desa ditetapkan oleh Kepala Desa setelah dibahas dan disepakati bersama Badan Permusyawaratan Desa. Rancangan Peraturan Desa tentang Anggaran Pendapatan dan Belanja Desa, pungutan, tata ruang, dan organisasi Pemerintah Desa harus mendapatkan evaluasi dari Bupati/Walikota sebelum ditetapkan menjadi Peraturan Desa. Hasil evaluasi diserahkan oleh Bupati/Walikota paling lama 20 (dua puluh) hari kerja terhitung sejak

${ }^{3}$ Ni'matul Huda, Perkembangan Hukum Tata Negara Perdebatan Dan Gagasan Penyempurnaan, (Yogyakarta:Fh UII Press, 2014), h. 393 
diterimanya rancangan Peraturan tersebut oleh Bupati/Walikota. Dalam hal Bupati/Walikota telah memberikan hasil evaluasi Kepala Desa wajib memperbaikinya. Kepala Desa diberi waktu paling lama 20 (dua puluh) hari sejak diterimanya hasil evaluasi untuk melakukan koreksi. Dalam hal Bupati/Walikota tidak memberikan hasil evaluasi dalam batas waktu, Peraturan Desa tersebut berlaku dengan sendirinya. Rancangan Peraturan Desa wajib dikonsultasikan kepada masyarakat Desa. Masyarakat Desa berhak memberikan masukan terhadap Rancangan Peraturan Desa. Peraturan Desa dan Peraturan Kepala Desa diundangkan dalam Lembaran Desa dan Berita Desa oleh sekretaris Desa. Dalam pelaksanaan Peraturan Desa, Kepala Desa menetapkan Peraturan Kepala Desa sebagai aturan pelaksanaannya.

Di dalam Pasal 70 ditentukan, Peraturan bersama Kepala Desa merupakan Peraturan yang ditetapkan oleh Kepala Desa dari 2 (dua) Desa atau lebih yang melakukan kerja sama antar-Desa. Peraturan bersama Kepala Desa sebagaimana dimaksud pada ayat (1) merupakan perpaduan kepentingan Desa masing-masing dalam kerja sama antar-Desa.

Lebih lanjut, Peraturan Desa merupakan Peraturan yang bersipat lokal. Peraturan Desa dibentuk berdasarkan asas-asas Peraturan perundang-undangan. A. Hamid S. Attamimi menyatakan, bahwa asas pembentukan Peraturan perundang-undangan yang patut khusus nya dalam ranah keindonesiaan, terdiri atas: Cita Hukum Indonesia, Asas Negara Berdasarkan Hukum, Asas Pemerintahan Berdasarkan Konstitusi dan asas-asas lainnya. ${ }^{4}$ Dalam pembentukan Peraturan perundang-undangan, disamping menganut asas-asas pembentukan perundangundangan yang baik, juga berlandasakan juga pada asas-asas hukum umum, yang terdiri atas asas hukum umum negara berdasarkan atas hukum, asas hukum umum pemerintahan berasarkan sistem konstitusi, asas hukum negara berdasarkan kedaulatan rakyat. ${ }^{5}$

Undang-Undang Nomor 12 Tahun 2011 tentang pembentukan Peraturan perundangundangan telah memberi pengakuan- terhadap Perdes sebagai Peraturan perundang-undangan di Indonesia. Yang dimaksud dengan Perdes menurut Undang-Undang Nomor 12 Tahun 2011 tentang Pembentukan Peraturan Perundang-Undangan adalah Peraturan perundang-undangan yang dibuat oleh Badan Perwakilan Desa atau dengan nama lainnya bersama dengan Kepala Desa atau nama lainnya. Tata cara penyusunan Uundang-Undang sampai dengan perda kabupaten/kota diatur dalam Undang-Undang Nomor 12 Tahun 2011, sedangkan ketentuan mengenai tata cara pembuatan Peraturan Desa di delegasikan oleh Undang-Undang Nomor 12 Tahun 2011 untuk diatur oleh Peraturan daerah Kabupaten/Kota yang bersangkutan.

\footnotetext{
${ }^{4}$ Yuliandri, 2009, Asas-asas Pembentukan Peraturan Perundang-undangan yang baik, Rajawali Pers, Jakarta, h. 24

5 Maria Farida Indrati, 1998, Ilmu Perundang-undangan, Kanisius, Yogyakarta, h. 196-197
} 
Pendelegasian mengatur tata cara pembuatan Peraturan Desa ini rupa-rupanya dimaksudkan untuk mengakomodasi keanekaragaman Desa di masing-masing Kabupaten atau Kota.

Sebelum berlakunya Undang-Undang Nomor 12 Tahun 2011 tentang Pembentukan Peraturan Perundang-Undangan, Peraturan Desa merupakan bagian Peraturan Daerah yang termasuk jenis Peraturan perundangan-undangan yang diatur dalam Pasal 7 ayat (2) huruf c Undang-Undang Nomor 10 Tahun 2004 tentang Pembentukan Peraturan PerundangUndangan. Setelah berlakunya Undang-Undang No. 12 Tahun 2011 tentang Pembentukan Peraturan Perundang-undangan, Peraturan Desa tidak disebutkan secara eksplisit sebagai salah satu Peraturan perundang-undangan. Akan tetapi, kedudukan Peraturan Desa sebenarnya masih termasuk Peraturan perundang-undangan. Hal ini didasarkan pada ketentuan Pasal 8 ayat 1 Undang-Undang Nomor 12 Tahun 2011:

"Jenis Peraturan Perundang-undangan selain sebagaimana dimaksud dalam Pasal 7 ayat (1) mencakup Peraturan yang ditetapkan oleh Majelis Permusyawaratan Rakyat, Dewan Perwakilan Rakyat, Dewan Perwakilan Daerah, Mahkamah Agung, Mahkamah Konstitusi, Badan Pemeriksa Keuangan, Komisis Yudisial, Bank Indonesia, Menteri, badan, lembaga atau komisi yang setingkat yang dibentuk dengan Undang-Undang atau Pemerintah atas perintah Undang-Undang, dewan Perwakilan Rakyat Daerah Provinsi, Gubernur, Dewan Perwakilan Rakyat Daerah Kabupaten/Kota, Bupati/ Walikota,

Kepala Desa atau yang setingkat.”

Diakuinya keberadaan Peraturan Desa dan mempunyai kekuatan hukum yang mengikat sepanjang diperintahkan oleh Peraturan yang lebih tinggi atau dibentuk berdasarkan kewenangan (formal), dipertegas dalam Pasal 8 ayat (2) Undang-Undang Nomor 12 Tahun 2011. Berdasarkan pada Pasal 101 Undang-Undang Nomor 12 tahun 2011, semua Peraturan perundang-undangan yang merupakan Peraturan pelaksana dari Undang-Undang Nomor 10 Tahun 2004, dinyatakan masih berlaku sepanjang tidak bertentangan dengan ketentuan Undang-Undang Nomor 12 Tahun 2011 tersebut. Walaupun pemerintah Desa tidak dapat begitu saja membentuk sebuah Peraturan Desa untuk menjabarkan sebuah Peraturan perundang-undangan ditingkat yang lebih tinggi jika tidak ada perintah dari Peraturan perundang-undangan atau pendelegasian karena urusan atau kewenangan asli yang diselenggarkan Desa sangat terbatas.

Selanjutnya Undang-Undang Nomor 6 Tahun 2014 tentang Desa Peraturan Desa ditetapkan oleh Kepala Desa setelah dibahas dan disepakati bersama Badan Permusyawaratan Desa merupakan kerangka hukum dan kebijakan dalam penyelenggaraan Pemerintahan Desa dan Pembangunan Desa. Penetapan Peraturan Desa merupakan penjabaran atas berbagai kewenangan yang dimiliki Desa mengacu pada ketentuan Peraturan perundang-undangan yang 
lebih tinggi. Sebagai sebuah produk hukum, Peraturan Desa tidak boleh bertentangan dengan Peraturan yang lebih tinggi dan tidak boleh merugikan kepentingan umum, yaitu: ${ }^{6}$

a. terganggunya kerukunan antarwarga masyarakat;

b. terganggunya akses terhadap pelayanan publik;

c. terganggunya ketenteraman dan ketertiban umum;

d. terganggunya kegiatan ekonomi untuk meningkatkan kesejahteraan masyarakat Desa; dan

e. diskriminasi terhadap suku, agama dan kepercayaan, ras, antar golongan, serta gender. Sebagai sebuah produk politik, Peraturan Desa diproses secara demokratis dan partisipatif, yakni proses penyusunannya mengikutsertakan partisipasi masyarakat Desa. Masyarakat Desa mempunyai hak untuk mengusulkan atau memberikan masukan kepada Kepala Desa dan Badan Permusyawaratan Desa dalam proses penyusunan Peraturan Desa.

Jenis Peraturan yang ada di Desa, selain Peraturan Desa adalah Peraturan Kepala Desa dan Peraturan Bersama Kepala Desa. Peraturan Desa dilarang bertentangan dengan kepentingan umum dan/atau ketentuan Peraturan perundang-undangan yang lebih tinggi. Sebagaimana yang di uraikab dalam BAB VII mengenai Peraturan Desa pada UndangUndang Nomor 6 Tahun 2014 tentang Desa ini yang berbunyi:

1) Jenis Peraturan di Desa terdiri atas Peraturan Desa, Peraturan bersama Kepala Desa, dan Peraturan Kepala Desa.

2) Peraturan sebagaimana dimaksud pada ayat (1) dilarang bertentangan dengan kepentingan umum dan/atau ketentuan Peraturan perundang-undangan yang lebih tinggi.

3) Peraturan Desa ditetapkan oleh Kepala Desa setelah dibahas dan disepakati bersama Bada Permusyawaratan Desa.

4) Rancangan Peraturan Desa tentang Anggaran Pendapatan dan Belanja Desa, pungutan, tata ruang, dan organisasi Pemerintah Desa harus mendapatkan evaluasi dari Bupati/Walikota sebelum ditetapkan menjadi Peraturan Desa.

5) Hasil evaluasi sebagaimana dimaksud pada ayat (4) diserahkan oleh Bupati/Walikota paling lama 20 (dua puluh) hari kerja terhitung sejak diterimanya rancangan Peraturan tersebut oleh Bupati/Walikota.

\footnotetext{
${ }^{6}$ Lihat Penjelasan Umum Undang-Undang Nomor 6 Tahun 2014 Tentang Desa.
} 
6) Dalam hal Bupati/Walikota telah memberikan hasil evaluasi sebagaimana dimaksud pada ayat (5), Kepala Desa wajib memperbaikinya.

7) Kepala Desa diberi waktu paling lama 20 (dua puluh) hari sejak diterimanya hasil evaluasi untuk melakukan koreksi.

8) Dalam hal Bupati/Walikota tidak memberikan hasil evaluasi dalam batas waktu sebagaimana dimaksud pada ayat (5), Peraturan Desa tersebut berlaku dengan sendirinya.

9) Rancangan Peraturan Desa wajib dikonsultasikan kepada masyarakat Desa.

10) Masyarakat Desa berhak memberikan masukan terhadap Rancangan Peraturan Desa.

11) Peraturan Desa dan Peraturan Kepala Desa diundangkan dalam Lembaran Desa dan Berita Desa oleh sekretaris Desa.

12) Dalam pelaksanaan Peraturan Desa sebagaimana dimaksud pada ayat (1), Kepala Desa menetapkan Peraturan Kepala Desa sebagai aturan pelaksanaannya.

1) Peraturan bersama Kepala Desa merupakan Peraturan yang ditetapkan oleh Kepala Desa dari 2 (dua) Desa atau lebih yang melakukan kerja sama antar-Desa.

2) Peraturan bersama Kepala Desa sebagaimana dimaksud pada ayat (1) merupakan perpaduan kepentingan Desa masing-masing dalam kerja sama antar-Desa.

Di dalam Undang Nomor 6 Tahun 2014 tentang Desa ternyata dinilai lebih longgar dalam melakukan desentralisasi kekuasaan terhadap Desa. Undang-undang tersebut kembali menghidupkan peran BPD sebagai parlemen Desa untuk melakukan pengawasan terhadap kebijakan Desa terutama dalam membentuk Peraturan Desa.

Apabila dilihat dari tata susunan (hierarki) dari semua jenis peratran perundangundangan di Indonesia, maka hal tersebut bukan hanya ditetapkan semata-mata, akan tetapi hal tersebut lebih dikarenakan Peraturan perundang-undangandi Indonesia selain dibentuk oleh lembaga yang berbeda, juga masing-masing mempunyai fungsi dan sekaligus materi muatan yang berbeda-beda sesuai dengan jenjangnya, sehingga hierarki, fingsi dan materi muatan Peraturan perundang-undangan itu selalu membentuk hubungan fungsional antara Peraturan perundangan yang satu dengan yang lain. ${ }^{7}$

Peraturan Desa merupakan suatu bentuk produk hukum yang dihasilkan oleh pemerintah di tingkat Desa yang dibuat oleh Badan Permusyawaratan Desa bersama kepala

\footnotetext{
${ }^{7}$ Maria Farida Indrati S., 2010. Ilmu Perundang-Undangan 1 (Jenis, Fungsi dan Materi Muatan), Yogyakarta: Kanisius, h. 235
} 
Desa dimana tata cara pembentukannya diatur oleh Peraturan Daerah Kabupaten/Kota yang bersangkutan. Peraturan Desa biasanya bersifat lokal dan biasanya berhubugan dengan Adat istiAdat Desa/masyarakat dan mengikat masyarakat setempat atau warga Desa lain yang tinggal sementara di Desa tersebut. ${ }^{8}$ Peraturan Desa juga merupakan penjabaran lebih lanjut dari Peraturan yang lebih tinggi dengan memperhatikan kondisi dan budaya masyarakat setempat.

Dalam menyusun Peraturan Desa terdapat batasan-batasan yang harus dijadikan acuan umum dalam penyusunan paraturan perundang-undangan. Berdasarkan ketentuan Pasal 5 Undang-Undang Nomor 12 Tahun 2011, dalam menyusun Peraturan perundang-undangan harus berdasarkan pada asas pembentukan Peraturan perundang-undangan yang baik, yang meliputi:

1. Kejelasan tujuan; bahwa setiap pembentukan Peraturan perundang-undangan harus mempunyai tujuan yang jelas yang hendak di capai;

2. Kelembagaan atau organ pembentuk yang tepat; bahwa setiap jenis Peraturan perundang-undangan harus dibuat lembaga/pejabat pembentuk Peraturan perundangundangan yang berwenang. Peraturan perundang-undang tersebut dapat dibatalkan atau batal demi hukum, bila dibuat oleh lembaga/pejabat yang tidak berwenang;

3. Kesesuaian antara jenis dan materi muatan; bahwa dalam pembentukan Peraturan perundang-undangan harus benar-benar memperhatikan materi muatan yang tepat dengan jenis perundang-undangannya.

4. Dapat dilaksanakan; bahwa dalam setiap pembentukan Peraturan perundangundangan harus memperhatikan efektifitas Peraturan perundang-undangan tersebut dalam masyarakat, baik secara filosofis, yuridis, maupun sosiologi;

5. Kedayagunaan dan kehasilgunaan; bahwa setiap Peraturan perundang-undangan dibuat karena memang benar-benar dibutuhkan dan bermanfaat dalam mengatur kehidupan masyarakat, berbangsa,dan bernegara;

6. Kejelasan rumusan; bahwa setiap Peraturan perundang-undangan harus memenuhi persyaratan teknis penyusun Peraturan perundang-undangan sistimatika, dan pilihan kata atau terminology, serta bahasa hukumnya jelas dan mudah dimengeri sehingga tidak menimbulkan berbagai macam interprentasi dalam pelaksanaannya;

7. Keterbukaa; bahwa dalam proses pembentukan Peraturan perundang-undangan, mulai dari perencanaan, persiapan, penyusunan, dan pembahasan bersipat transparan dan

\footnotetext{
${ }^{8}$ http://carapedia.com/peraturan_desa_info661.html (Diakses pada tanggal 21 Oktober 2015)
} 
terbuka. Dengan demikian seluruh lapisan masyarakat mempunyai kesempatan yang seluas-luasnya untuk memberikan masukan dalam proses pembentukan Peraturan perundang-undangan.

Berdasarkan dari keseluruhan penjelasan di atas, maka penulis dapat simpulkan bahwa kedudukan Peraturan Desa sebagai produk hukum Desa telah memiliki pijakan yuridis yang sangat kuat. Meskipun demikian, masih ada kekosongan pengaturan mengenai pembatalan Peraturan Desa. Apabila rancangan Peraturan Desa yang diperintahkan untuk dievaluasi oleh Bupati/Walikota tidak ditindaklanjuti oleh kepala Desa sehingga rancangan Peraturan Desa tersebut tetap disahkan menjadi Peraturan Desa, Undang-Undang Nomor 6 tahun 2014 tentang Desa tidak memberikan ketegasan. Prinsip yang ditentukan dalam undang-undang tersebut hanyalah pada pengawasan preventif (executive preview), padahal dengan adanya limpahan dana yang besar ke Desa dan nantinya harus dipayungi oleh Peraturan Desa, pengaturan mengenai pengawasan refresif juga diperlukan sebagai antisipasi lahirnya produk hukum yang koruptif dibelakang hari. Lebih dari itu bahwa, meskipun Peraturan Desa sudah tidak lagi muncul di dalam hierarki Peraturan perundangundangan setelah lahirnya atau berlakunya Undang-Undang Nomor 12 Tahun 2011 Tentang Pembentukan Peraturan perundang-Undangan, namun keberadaannya diatur secara tegas dan kedudukan Peraturan Desa semakin kuat karena telah dijadikan sandaran yuridis pengaturan Desa dengan terbitnya Undang-Undang Nomor 6 Tahun 2014 Tentang Desa.

Undang-Undang Nomor 12 Tahun 2011 Tentang Pembentukan Peraturan PerundangUndangan tetap mengakui keberadaan Peraturan Desa sebagaimana yang ditentukan dalam Pasal 8 ayat (2), yang menyatakan Peraturan perundang-undangan sebagaimana yang dimaksud pada ayat (1) diakui keberadaannya dan memiliki kekuatan hukum mengikat sepanjang diperintahkan oleh Peraturan perundang-undangan yang lebih tinggi atau dibentuk berdasarkan kewenangan. Dalam konteks Undang-Undang Nomor 12 Tahun 2011 Tentang Pembentukan Peraturan Perundang-Undangan, hierarki Peraturan perundang-undangan tidak lagi semata-mata didasarkan hierarki struktural, tetapi juga dianut hierarki fungsional, sehingga secara fungsional Peraturan Desa bukan produk hukum yang dilarang, tetapi tetap diakui keberadaanya dan memiliki daya ikat hukum. Dihapusnya Peraturan Desa dari hierarki Peraturan perundang-undangan tidak menimbulkan implikasi atau dampak terhadap penyelenggaraan pemerintahan Desa, karena BPD tetap dapat membentuk Peraturan Desa bersama dengan kepala Desa atas dasar yang kuat yaitu Undang-Undang Nomor 6 Tahun 2014 Tentang Desa. 


\section{Kesimpulan}

Bahwa kedudukan peraturan desa dalam sistem peraturan perundangundangan masih tetap diakui dan kedudukan Peraturan Desa sebagai produk hukum Desa telah memiliki pijakan yuridis yang sangat kuat dengan lahirnya UndangUndang Nomor 6 Tahun 2014 Tentang Desa.

Meskipun Peraturan Desa sudah tidak lagi muncul di dalam hierarki Peraturan perundang-undangan setelah lahirnya atau berlakunya Undang-Undang Nomor 12 Tahun 2011 Tentang Pembentukan Peraturan perundang-Undangan, namun keberadaannya diatur secara tegas dan kedudukan Peraturan Desa semakin kuat karena telah dijadikan sandaran yuridis pengaturan Desa dengan terbitnya UndangUndang Nomor 6 Tahun 2014 Tentang Desa.

Undang-Undang Nomor 12 Tahun 2011 Tentang Pembentukan Peraturan Perundang-Undangan tetap mengakui keberadaan Peraturan Desa sebagaimana yang ditentukan dalam Pasal 8 ayat (2), yang menyatakan Peraturan perundang-undangan sebagaimana yang dimaksud pada ayat (1) diakui keberadaannya dan memiliki kekuatan hukum mengikat sepanjang diperintahkan oleh Peraturan perundangundangan yang lebih tinggi atau dibentuk berdasarkan kewenangan. Dalam konteks Undang-Undang Nomor 12 Tahun 2011 Tentang Pembentukan Peraturan PerundangUndangan, hierarki Peraturan perundang-undangan tidak lagi semata-mata didasarkan hierarki struktural, tetapi juga dianut hierarki fungsional, sehingga secara fungsional Peraturan Desa bukan produk hukum yang dilarang, tetapi tetap diakui keberadaanya dan memiliki daya ikat hukum.

Dihapusnya Peraturan Desa dari hierarki Peraturan perundang-undangan tidak menimbulkan implikasi atau dampak terhadap penyelenggaraan pemerintahan Desa, karena BPD tetap dapat membentuk Peraturan Desa bersama dengan kepala Desa atas dasar yang kuat yaitu Undang-Undang Nomor 6 Tahun 2014 Tentang Desa.

\section{Daftar Pustaka}

\section{A. Buku-Buku}

Astawa, I Gde Pantja dan Suprin Na'a. 2008. Dinamika Hukum Dan Ilmu PerundangUndangan Di Indonesia. Bandung: PT ALUMNI.

Marzuki, Peter Mahmud. 2009. Penelitian Hukum. Jakarta : PT Interpratama Offset. 
Mas, Marwan, 2003. Pengantar Ilmu Hukum. Makassar : GHALIA INDONESIA

Soehino. 2006. Hukum Tata Negara Teknik Perundang-Undangan. Yogyakarta: Anggota IKAPI.

Soeprapto, Maria Farida Indrati. 2007. Ilmu Perundang-Undangan, Jenis, Fungsi Dan Materi Muatan. Yogyakarta: KANISIUS.

Sukriono, Didik. 2010. Pembaharuan Hukum Pemerintahan Desa, Politik Hukum Pemerintahan Desa Di Indonesia. Malang: Setara Fress (Kelompok InTRANS Publishing.

Wasistiono, Sadu dan M. Irwan Tahir. 2007. Prospek Pengembangan Desa. Bandung: CV. FOKUS MEDIA-Anggota IKAPI.

Widjaja, HAW. 2003. Pemerintahan Desa/Marga Berdasarkan Undang-Undang Nomor 22 Tahun 1999 Tentang Pemerintahan Daerah. Jakarta: PT Raja Grapindo Persada.

----- 2004. Otonomi Desa Merupakan Otonomi Yang Asli Bulat Dan
Utuh. Jakarta: PT Raja Grapindo Persada.

\section{B. Peraturan Perundang-undangan}

a. Undang-Undang Dasar Negara Republik Indonesia Tahun 1945;

b. Undang-Undang Republik Indonesia Nomor 32 Tahun 2004 Tentang Pemerintahan Daerah (Lembaran Negara No. 125 Tahun 2004, Tambahan Lembaran Negara No. 4437);

c. Undang-Undang Nomor 12 Tahun 2011 Tentang Pembentukan Peraturan Perundangundangan (Lembaran Negara No.82 Tahun 2011, Tambahan Lembaran Negara Nomor 5234);

d. Peraturan Pemerintah Nomor 72 Tahun 2005 Tentang Desa ( Lembaran Negara Nomor 158 Tahun 2005, Tambahan Lembaran Negara Nomor 4587); 